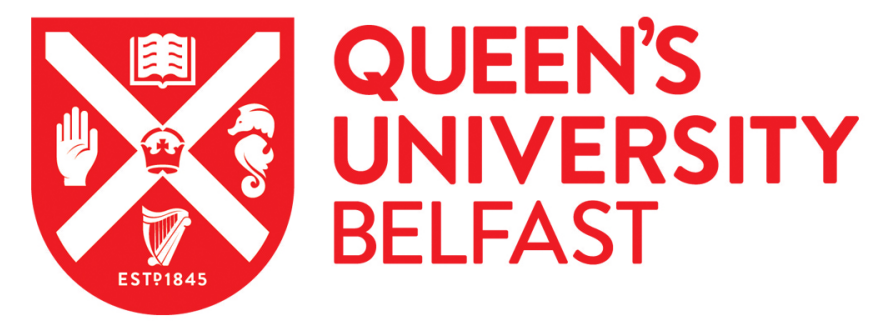

\title{
Yeats, Dates and Kipling: 1912, 1914, 1916
}

Brearton, F. (2018). Yeats, Dates and Kipling: 1912, 1914, 1916. Modernist Cultures, 13(3), 305-322.

https://doi.org/10.3366/mod.2018.0214

\author{
Published in: \\ Modernist Cultures
}

Document Version:

Peer reviewed version

Queen's University Belfast - Research Portal:

Link to publication record in Queen's University Belfast Research Portal

Publisher rights

(C) 2018 Edinburgh University Press.

This work is made available online in accordance with the publisher's policies. Please refer to any applicable terms of use of the publisher.

\section{General rights}

Copyright for the publications made accessible via the Queen's University Belfast Research Portal is retained by the author(s) and / or other copyright owners and it is a condition of accessing these publications that users recognise and abide by the legal requirements associated with these rights.

Take down policy

The Research Portal is Queen's institutional repository that provides access to Queen's research output. Every effort has been made to ensure that content in the Research Portal does not infringe any person's rights, or applicable UK laws. If you discover content in the Research Portal that you believe breaches copyright or violates any law, please contact openaccess@qub.ac.uk. 
Yeats, Dates, \& Kipling: 1912, 1914, 1916

I.

The celebrations and commemorative events that were held in Dublin in 2016 to mark the $100^{\text {th }}$ anniversary of the Easter Rising took place not on the Rising's anniversary date $\left(24^{\text {th }}\right.$ April), but almost a month earlier, on Easter weekend, $27^{\text {th }}-28^{\text {th }}$ March. ${ }^{1}$ In making that decision, clearly practical considerations were at work; but it was a symbolic gesture too, recognising the powerful presence of 'Easter' in the Rising's mythology. One hundred years earlier, Yeats made a similar choice in titling the poem which both remembered and shaped future memory of the event, 'Easter 1916'. In doing so he was, as Nicholas Grene points out, 'very obviously drawing on the associations intended by the rebels in choosing their time for the Rising, the suggestions implicit in the word "Rising" itself. The rebellion is a resurrection, a re-birth of the nation...' ${ }^{2}$ Easter, the moveable feast that is yet always the same carries associations beyond simply this Easter, 1916, to mark a cyclical pattern of sacrifice and renewal: the emphasis is on time rather than place - alternatives might well have been 'Dublin 1916' or 'Ireland 1916' - and, moreover (in the choice of 'Easter' rather than 'April'), on time in its intersection with what is 'timeless'.

If 'Easter' in Yeats's title is evocative, engaged in a complex intertextual relation with the cultural energies that fed the Rising, so too is the dating and numbering in the poem, which enters into dialogue with key moments in Yeats's own oeuvre. As Grene reminds us, 'Yeats himself was aware, even as he was writing "Easter 1916" of the way it talked back to "September 1913", 3 'September' is ordinary time, evoked again at the close of 'Easter 1916' 
where he dates the poem 'September 25, 1916'; 'Easter' is sacred time. In 'September 1913' Yeats laments a 'Romantic Ireland' as 'dead and gone'; 'Easter 1916 marks its resurgence in a new and 'terrible beauty'. Both poems are preoccupied with numbers; but the counting of 'September 1913', the debased adding of 'the half pence to the pence' and 'prayer to shivering prayer' becomes the heroic numbering of 'Easter 1916': 'Yet I number him in the song', he says of McBride. At the poem's close, 'our part' is to 'save' in a rather different sense from the 'pray and save' of 'September 1913' since to 'murmur name upon name' in 'Easter 1916 ' is to preserve. Comedy gives way to tragedy; the 'delirium of the brave' mourned in 'September 1913' becomes the 'excess of love' which 'Bewildered them till they died'. ${ }^{4}$ Playing on the (Renaissance) definition of poetry as numbers, 'Easter 1916' counts in a different sense too, encoding the Rising's date in its four sections of 16, 24, 16 and 24 lines, ${ }^{5}$ as well as literally 'counting' in its lines the 16 dead men.

We might usefully consider this alongside another famous date-inflected poem, Yeats's 'Nineteen Hundred and Nineteen'. Originally published in The Dial in September 1921 as 'Thoughts upon the Present State of the World', 'Nineteen Hundred and Nineteen' then carried the date 'May 1921' in the note after the text. Like 'Easter 1916' it is a Spring and September poem in conception and realisation, and its retitling serves a purpose in a context where the poem talks back to 'Easter 1916' as 'Easter 1916' talked back to 'September 1913'. 'Nineteen' (literally) turns 'sixteen' on its head, in the shift from the emergence of a 'terrible beauty' in 'Easter 1916', to 'Many ingenious lovely things are gone'; from 'We know their dream; enough / To know they dreamed and are dead', to 'the nightmare' that 'Rides upon sleep'. The speaker repenting his 'mocking tale or gibe' in 'Easter 1916' in the face of tragedy adopts in 'Nineteen Hundred and Nineteen' an embittered collective voice invoking mockery of 'the great', 'the wise, the good', and mockers themselves, 'for we / Traffic in mockery'. In the 'living stream' of 'Easter 1916, 'A horse-hoof slides on the brim, / 
And a horse plashes within it'; by 'Nineteen Hundred and Nineteen', the horses of 'delicate sensitive ear or tossing mane...wearied running round and round in their courses / All break and vanish, and evil gathers head' ${ }^{6}$

The association of the dates 1913, 1916 and 1919 with Yeats is powerful, in part because Yeats made it so as he negotiated and renegotiated his response to important events in Ireland. The poems are tied to the 'Irish story' and the dates are symbolic - particularly 1916. But there is another subtext to 'Easter 1916' which evokes dates less visible in Yeats, and which brings into focus different elements of the Irish story in the broader context of the First World War. As Nicholas Grene points out, when 'Nineteen Hundred and Nineteen' appeared in 1921 the lines 'We, who seven years ago / Talked of honour and of truth' would have been taken by its first reader as referring 'unmistakeably to 1914, the last year of the pre-war illusions'. The change in title 'removes the attention from 1914 to the less significant $1912^{7}$ - less significant at least on the global stage. As such, it is a change in keeping with Yeats's professed views on the First World War: he was later to argue that while 'established things were shaken by the Great War' in English letters, Irish poetry 'moves in a different direction and belongs to a different story'. ${ }^{8}$

That the elision of 1914 brings 1912 into play is suggestive given the extent to which 'Easter 1916' might be read as engaged, intertextually, with more than the Rising's own sacrificial rhetoric or Yeats's own oeuvre. One context for 'Easter 1916' is the tradition of dated title poems which reflect upon the 'state of the nation' - Wordsworth's 'London 1802', Shelley's 'England in 1819' - as well as those poems knowingly poised on the cusp of momentous historical change, poems whose dating may be a form of political intervention, designed to capture as well as create cultural 'memory' of the time: they include, in the years preceding 'Easter 1916', Rudyard Kipling's 'Ulster (1912)' and Rupert Brooke’s '1914 \& Other Poems'; or, a generation later (with its consciousness of Yeats's 'September 1913' and 
'Easter 1916'), W.H. Auden's 'September 1, 1939'. And when Yeats wrote 'Easter 1916', he was doing so in a context where Rudyard Kipling's 'Ulster (1912)' had received quite extraordinary levels of press coverage four years earlier. Behind the 1913, 1916, 1919 sequence made visible by Yeats, I therefore wish to propose a different pattern implicitly evoked (as well as repudiated) in Yeats's work, running through 1912 (the Home Rule crisis), 1914 (the passing of the Home Rule Bill and the outbreak of war), and 1916 (the year of unionist 'sacrifice' on the Somme). To acknowledge that 'Easter 1916' talks back to 'Ulster (1912)', that we might read this poem, and the 1913 and 1919 titled poems standing on either side of it, as engaged in an implicit, perhaps even unconscious, quarrel with Rudyard Kipling - more precisely, with what Kipling, in Yeats's mind, stands for - is to reorient perceptions of how and where certain kinds of (sacrificial) rhetoric are deployed in the context of Irish pre-war and wartime history.

II.

W.H. Auden invented a parlour game he called 'Purgatory Mates' in which players 'had to choose two persons of such different character that they would naturally hate each other, but who were condemned to live together in Purgatory until they had reached a state of mutual love; examples of such pairs were T.S. Eliot and Walt Whitman, and Tolstoy and Oscar Wilde'. ${ }^{9}$ Another example might well be Yeats and Kipling - the Irish nationalist versus the Anglo-Indian imperialist. Seldom mentioned in the same breath, Yeats and Kipling led oddly parallel lives. Both were born in 1865, and although they apparently never met (talking of Sunday evenings at W.E. Henley's, Yeats notes that 'Kipling came sometimes, I think, but I never met him ${ }^{10}$ ) their points of connection, at least on the surface, are several. They were the first two English language writers to receive the Nobel Prize - Kipling in 1907, Yeats in 
1923. Both have a fin-de-siècle fascination with India. At the point where Kipling was admitted into the freemasons, in 1885, Yeats was immersing himself in the world of the Hermetic Order of the Golden Dawn. Both were elected to the Academic Committee of English letters in 1910. Yeats outlived Kipling by exactly three years (Kipling died in January 1936, Yeats in January 1939). Yet every point of apparent connection manifests an extreme divergence in views, certainly after 1900, on everything from politics, to literature, to theatre, to music hall, to theosophy, to freemasonry, to W.E. Henley's free verse.

In the recent (and only) comparative study of Yeats and Kipling in the late $19^{\text {th }}$ century, Alexander Bubb observes that Kipling was added to the list of Yeats's enemies only in the context of the Second Anglo-Boer War of 1899-1902. The war, he suggests, 'provoked the imperialist in Kipling and the nationalist in Yeats to part ways'. ${ }^{11}$ In 1903 Yeats's views were reported as: 'latterly he has turned himself into a kind of imperialist journalist in prose and verse, and with all that I have no sympathy. Ten years ago Kipling mattered greatly to men of letters - today he matters much to journalists. His might have been a very great name indeed, but he has made what Dante calls "the great refusal" — the refusal to be himself." 12 Writing to his father in c. 1909 , the point is more nuanced:

I was delighted with your letter insisting on 'intimacy' as the mark of fine literature. The contrary thing to this intimacy, which is another name for experience, life, is I believe 'generalization.' And generalization creates rhetoric, wins immediate popularity, organizes the mass, gives political success, Kipling's poetry, Macauley’s essays and so on. Life is never the same twice and so cannot be generalized. When you go from an Irish country district, where there are good manners, old songs, old stories and good talk, the folk mind, to an Irish country town, generalization meets one in music-hall songs with their mechanical rhythm, or in thoughts taken from the newspapers. ${ }^{13}$ 
It is easy to see here how and why Kipling serves as negative example for Yeats, given Yeats's opposition to 'the mass', to rhetoric and generalization, to journalism and the music hall - all traits he associated with English influence and culture, and traits he was later to associate with the Great War. Yeats's criticisms of '[c]ontemporary English literature' (for its 'delight in praising England and her Empire, the masterwork and dream of the middle class' ${ }^{14}$ and of the British Press, as understanding only the kind of patriotism 'that makes a man say "I need not trouble to get wisdom for I am English \& my vices have made me great", which were articulated in the Anglo-Boer War, set the terms, as I have argued elsewhere, for his reactions to the First World War. ${ }^{15}$ He also felt, as James Longenbach has shown, a 'certain contempt for the poems that treated the experience of war directly and filled the daily papers'. ${ }^{16}$ In the 1930 s Yeats also echoes some of the terms of his letter to J.B. Yeats in relation to the Great War, arguing that Ireland's 'still living folk tradition' rendered it immune from the deleterious effects on the English literary tradition of a war he called at the time 'bloody frivolity' ${ }^{17}$ (that is, not worthy of serious attention). The 'social passion' of the war poets, which, he claims, eventually gives way in England to 'an impersonal philosophical poetry', contrasts with an Irish tradition in which poets have 'hardened and deepened their personalities'. ${ }^{18}$ J.B. Yeats himself refers to Kipling (in 1909) as someone who 'give[s] people what they like', and in 1913 writes that 'Kipling is all tinsel and vulgarity and both elaborated ${ }^{19}$ - a criticism that finds an odd echo more than twenty years later in Yeats's infamous 1936 comment on Wilfred Owen that '[h]e is all blood, dirt and sucked sugar-stick' ${ }^{20}$

That Yeats and Kipling finally 'meet' on rather unexpected ground, in Auden's 'In Memory of W.B. Yeats', where both are indicted for questionable 'views', one might take as Auden's 'purgatory mates' sense of humour at work:

Time that with this strange excuse 
Pardoned Kipling and his views,

And will pardon Paul Claudel,

Pardons him for writing well..$^{21}$

In the opening of this section - 'Earth receive an honoured guest / William Yeats is laid to rest' - the rhythmical debt to Yeats's 'Under Ben Bulben' is habitually acknowledged; but the lines are also indebted to Kipling's 'A Charm': 'Take of English earth as much / As either hand may rightly clutch",22 And in drawing the two into a shared rhythmical space Auden is particularly astute, since there is a precedent already set in the encounter between Yeats's 'Easter 1916' and Kipling’s 'Ulster (1912)'.

'Ulster (1912)'was first published in the Morning Post on 9 April 1912, Easter Tuesday, simply titled 'Ulster'. It was not collected until some years later, in The Years Between, Kipling's 1919 volume of First World War poems, when its subtitle (1912) was added. It was written to coincide with Asquith's introduction of the third Home Rule Bill on 11 April 1912, and in it Kipling argues fiercely for the betrayal of unionism and Protestantism:

The Faith in which we stand,

The laws we made and guard -

Our honour, lives, and land -

Are given for reward

To Murder done by night,

To Treason taught by day,

To folly, sloth, and spite,

And we are thrust away. 
The blood our fathers spilt,

Our love, our toils, our pains,

Are counted us for guilt,

And only bind our chains.

Before an Empire's eyes

The traitor claims his price.

What need of further lies?

We are the sacrifice. ${ }^{23}$

Everything Yeats disliked about the progress of Kipling's career and the kind of writer he became (as also about his politics) is encapsulated in the publication and reception of 'Ulster (1912)': it is a poem which, one might reasonably argue, in its 'mechanical rhythm' also 'creates rhetoric, wins immediate popularity [in certain quarters], organizes the mass, gives political success' - or at least is designed to do so.

In stark contrast with the later 'Easter 1916' which was, initially at least, circulated only to a private audience and with extreme caution on Yeats's part, ${ }^{24}$ Kipling was determined to promote the popular reach of 'Ulster [1912]' with all expediency. As Andrew Lycett points out, he enlisted the help of Cope Cornford, urging him to "“Get the last ounce of work out of it"', and he took 'care to emphasise that each reproduction must carry a copyright. Otherwise, he said, he would miss the fun of fining the pro-Irish journals in the United States, which would assuredly steal it'. 'Ulster (1912)' was discussed in the House of Commons, where 'a Liberal MP asked the Attorney-General if Rudyard would be prosecuted for producing these seditious verses', in response to which James Craig suggested he should recite the poem aloud to enable the full understanding of the House, and William Redmond responded with: "“Will the right hon. Gentleman bear in mind that in general opinion this doggerel ought not to be called verse at all"'.25 The publication of the poem thus became a 
'story' that led to its reprinting, in part or in whole, in a number of the Irish papers in the days that followed its first Easter Tuesday appearance. And it provoked in Ireland some Easter week responses which included an open letter to Kipling by AE, and a poem written in response by Tom Kettle, the Home Rule barrister and MP later to be killed on the Somme in 1916.

Kipling's poem invokes the rhetoric of sacrifice, of 'honour' and truth, here tied, in stark contrast to the pre-war sacrificial writings of, for instance, Padraic Pearse, to an antiCatholic sentiment which was to prove the most controversial aspect of the poem: 'We know the war prepared / On every peaceful home, / We know the hells declared / For such as serve not Rome'. The epigraph quotation from Isaiah, lix.6 (Their webs shall not become garments, neither shall they cover themselves with their works: their works are works of iniquity and the act of violence is in their hands) and the call to arms were also inflammatory. AE's (lengthy) open letter to Kipling concludes:

I set my knowledge, the knowledge of a lifetime, against your ignorance, and I say you have used your genius to do Ireland and its people a wrong. You have intervened in a quarrel of which you do not know the merits like any brawling bully who passes, and only takes sides to use his strength. [...] You had the ear of the world and you poisoned it with prejudice and ignorance. You had the power of song and you have always used it on behalf of the strong against the weak. ${ }^{26}$

Tom Kettle countered Kipling on 11 April 1912 with ‘A Note on Mr Rudyard Kipling’s Fantasia in the "Morning Post", a six-stanza poem mimicking Kipling's form in which a 'Lenten' Ireland is about to come to fruition in the resurrection of her true self:

The red, redeeming dawn Kindled in Easter skies, 
Falls like God's judgement on

Lawyers and lords and lies.

What care these evil things,

Though menaced and perplex,

While Kipling's banjo strings

Blaspheme a sacred text?

$[\ldots]$

So now when Lenten years

Burgeon at last to bless

This land of faith and tears

With fruitful nobleness,

The poet for a coin

Hands to the gabbling rout

A bucketful of Boyne

To put the sunrise out.

$[\ldots]$

We keep the elder faith,

Not slain by Cromwell's sword,

Nor bribed to subtler death

By William's broken word.

Free from those chains and free,

From hate for hate endured,

We share the liberty

Our lavish blood assured. 
One place, one dream, one doom,

One task and toil assigned,

Union of plough and loom

Have bound us and shall bind

The wounds of labour healed,

Life rescued and made fair,

There lies the battlefield

Of Ulster's holy war. ${ }^{27}$

It is its own kind of 'doggerel', clearly written in haste. (That said, it betters some of the other poetic offerings prompted by 'Ulster (1912)', among them the effort by 'P.J.C' which begins 'If Mr Rudyard Kipling / Were a thoughtless, beardless stripling / Or a rhymester fond of tippling, / I could straightway understand / His base insinuation / Against a sister nation / And his foul vituperation / Of an undertrodden land' ${ }^{28}$ ) Nevertheless, the point to register is that Kettle's poem, published in Ireland in 1912's Easter week, is written predominantly in the mode later associated with 1916: the Easter sacrifice that will bring redemption, the return of nobility. Kipling's timing may have been determined by parliament, but the poem's insistence on 'The blood our fathers spilt' and 'the sacrifice' suggests some Easter resonance, immediately then reclaimed by Kettle for the ‘elder faith' of Roman Catholicism. Picked up by other local papers, Kettle's 'Fantasia' was reprinted several times through April and May 1912. Kipling's unionist 'One Law, one Land, one Throne' becomes in Kettle 'One place, one dream, one doom', which is akin to the single-minded 'Heart with one purpose alone...Enchanted to a stone' later evoked by Yeats in relation to the doomed 1916 rebels.

Yeats didn't enter the fray in the Irish press, at least not concerning Kipling's poem; but as R.F. Foster notes, he was 'closely interested in the progress of the Home Rule legislation mooted from early 1912'. Although 'not immune to Protestant fears about 
Catholic ambitions to control free thought in an independent Ireland', he was 'none the less well aware that this could be manipulated for purely political ends. And in April he put his name to a public letter from 56 Irish Protestants who supported Home Rule...'. ${ }^{29}$ That letter - published in the Irish Times in Easter week, and published two columns along from Kettle's riposte to Kipling in the Freeman's Journal - begins 'As Protestants resident in Dublin... we desire to mark otherwise than by mere words, our disapproval of the statement that Protestants in the Southern parts of Ireland live in fear of their Catholic neighbours. // It seems to us absurd to suppose that a difference in religious belief involves conflicting interests between ourselves and our fellow-countrymen. ${ }^{30}$

Undeterred by hostility from Irish quarters - in fact rather courting it - Kipling entered the arena again in Easter 1914, signing a British Covenant declaration in March, ${ }^{31}$ followed by a Hyde Park rally on 4 April. He then campaigned for the 'League of British Covenanters' through May, and was the 'principal speaker' at a Tunbridge Wells anti-Home Rule rally on 16 May $1914 .{ }^{32}$ His speech on that occasion, entitled 'Rudyard Kipling's Indictment of the Government', was then 'sold for 1d at the news stalls'. ${ }^{33}$ On 20 May, Kipling's 'The Covenant' appeared (ornately printed, with his signature reproduced at the end) in the The Covenanter, a London publication that seems only to have survived through one issue. A sonnet which is a unionist call to arms, effectively claiming God to be on their side, it concludes:

Yet there remains His Mercy - to be sought

Through wrath and peril till we cleanse the wrong

By that last right which our forefathers claimed

When their Law failed them and its stewards were bought.

This is our cause, God help us, and make strong

Our will to meet Him later, unashamed. ${ }^{34}$ 
The poem was reprinted in The Times and the Daily Telegraph on 22 May 1914, and as Ann Parry notes, 'It is doubtful whether any other verse by an English writer has ever secured such a wide-ranging readership at a crucial moment in the development of an affair', ${ }^{35}$

III

The Home Rule Bill was passed into law on 18 September 1914, but suspended for the duration of a war that had shifted government priorities in the summer of 1914 - and had shifted Kipling's priorities too. By September 1914, rather than lamenting the sacrifice of Ulster, he was calling for a voluntary 'iron sacrifice / Of body, will and soul' in his poem 'For All We Have and Are': 'Who stands if freedom fall? / Who dies if England live?'36 Nevertheless, it is worth recalling that the ' 25 September' date at the close of 'Easter 1916' is also only three days away from the fourth anniversary of September 1912's 'Ulster Day', and two years on from the Home Rule Bill reaching the statute books. Those facts may be more than adventitious in a context where 'Easter 1916' can be read as talking back to Easter 1912, to 'Ulster (1912)', and to the sacrificial rhetoric there employed. 'Easter' carries a sonic echo of 'Ulster' but writes over place with time, rigidity with renewal. The relentlessly quoted (in the press) lines by Kipling 'What need of further lies? / We are the sacrifice' become in Yeats the more complex 'Too long a sacrifice / Can make a stone of the heart' - Yeats's first use of the word 'sacrifice' in his poems. (He uses it once more, in 'Parnell's Funeral', where the popular hysteria that dragged Parnell down is once again earlier voiced by Kipling in the poem 'Cleared' from $1890 .{ }^{37}$ ) The language of resistance in Kipling (we 'stand', we 'cleave', we shall not 'yield'), contrasts with Yeats's insistence in 'Easter 1916' on movement, fluidity, and change, 'minute by minute'. The brash confidence and Godlike presumption of Kipling's 'What answer from the North? / One Law, one Land, one Throne' in 'Ulster 
(1912)' is light years away from a rhythmically echoing but much more profound question and answer in Yeats: 'O when may it suffice? / That is heaven's part...' 'England's act and deed' in betraying 'The Faith' in 'Ulster (1912)' contrasts, ironically enough given the politics involved, with 'For England may keep faith / For all that is done and said' - Yeats's only direct allusion in the poem to the context of the Great War.

Kipling's rhythm in 'Ulster (1912)' is that mechanical rhythm subordinate to the rhetoric, a relentless, unvarying iambic drum banging through the poem in a strictly adheredto six-syllable three-beat line, matching its repetition of rhetorical 'threes' ('Rebellion, rapine hate'; 'honour, lives and land'; 'Our love, our toils, our pains' and so on.). There are a few instances of that base-line rhythmical pattern in 'Easter 1916'(where it is reasonably unequivocal that is), from none at all in the first stanza, to a couple of lines in the second ('Untíl her vóice grew shríll...And róde our wíngéd hórse’); three in the third ('Enchanted to a stone'; 'From cloud to tumbling cloud'; 'And hens to moor-cocks call'); and at least six in the fourth, among them: 'O when may it suffice'; 'For England may keep faith', 'Wherever green is worn'. In an 80-line poem, those lines, rhythmically, feel like the pull towards the kind of public political poem (one that would please rather than, as it turned out, displease everyone) 'Easter 1916' also knows it cannot become. Rather, the rhythmical complexities which characterise 'Easter 1916' put that 'public' (Kiplingesque) mode in tension with private doubt. In 'Easter 1916' we witness a struggle between the individual, or personal response, Yeats's desire to shape collective memory, and the pressures of history that, conversely, shape the poem. Its complexities of voice and rhythm expose the crudity of Kipling's 'refusal to be himself', as Yeats earlier put it, in the unequivocal collective voice we hear in 'Ulster (1912)' or 'The Covenant' - a voice which by holding fast to its political certainties attempts to 'bully' historical time. 
As with the 'Easter' of the title - the moveable feast that is yet always the same 'Easter 1916' encapsulates, even in its rhythms, the tension between continuity and change Its quarrels are played out, appropriately enough for a numbers-minded poet in a numbering song, between twos and threes and multiples thereof: between trochaic/iambic, dactylic/anapaestic, 2 feet/3 feet lines. With 'A térrible béauty is bórn...' we move from duple into triple feet, and to threes in the consonants too, on b-b-b. The three remains embedded in 'I write it out in a verse' (on t-t-t) but the line puts the poet and the event in contention: Í write it oút in a vérse' (triple feet) as the active prioritisation of the poet's role in shaping memory; or more passively, with the poet recording rather than shaping the past, 'I wríte it oút' (duple feet, and a more predictable iambic). Brooding on the point where passionate commitment becomes a terrifying intransigence, 'Easter 1916' ultimately recognises the 'All changed, changed utterly' of its time, but it holds some ground rhythmically (in a four-stress spondaic line) against that change even in the acknowledgment of it. In its second iteration however, it becomes a resounding three stress line: 'Are chánged, chánged útterly'. In playing out twos against threes, 'Easter 1916'’s rhythms reverberate in the patterns of history Yeats was prone to trace through the (mis)dating within his own oeuvre. The poem also implicitly evokes and simultaneously discards the mechanical rhythm, mass appeal, the working 'on the surface' he associates with 'popular poetry', with mere rhetoric - with Kipling.

The complex positioning of 'Easter 1916' in relation to the Rising is often noted; but its implicit dialogue with a Kiplingesque mode suggests also an engagement with, and subtle response to, the political and sectarian quarrels of 1912-14. It is notable too that for all Yeats (deceptively) claimed to ignore the First World War, the echoes of Kipling in Yeats in the period 1916-1921 are unmistakeable. The war years bring Kipling once more into critical focus for Yeats, as the Boer War had done earlier, and Yeats's wartime and immediate post- 
war poems rework the language and rhetoric of his imperialist contemporary. In the opening stanza of Kipling's 'Ulster (1912)':

The dark eleventh hour

Draws on and sees us sold

To every evil power

We fought against of old.

Rebellion, rapine, hate,

Oppression, wrong and greed

Are loosed to rule our fate,

By England's act and deed.

That 'evil power' in Kipling, with all its historical and sectarian specificity, is transformed into a more fundamental struggle in Yeats's 'evil gathers head' ('Nineteen Hundred and Nineteen'): the poet less apparently engaged with the First World War absorbs with greater philosophical intensity the sense of global catastrophe, capturing the time without narrowing it down to place. The victimised group with whom Kipling identifies - who are subject, in his argument, to the various injustices 'loosed' by England 'to rule our fate' - suggests something of the 'passive suffering' to which Yeats objected in his 1936 critique of Wilfred Owen and others of the war poets who 'felt bound ...to plead the suffering of their men' ${ }^{38}$

By contrast, in Yeats's differently pitched 'eleventh hour' 'The Second Coming', it is 'Mere anarchy' that is 'loosed upon the world' in a poem whose resistance and excitement are generated by its rhythm and repetitions in equal measure. Bubb points to the more 'didactic' morality at work in Kipling's apocalyptic poems of this period;' '[m]ere anarchy', however, (with 'mere' in its sense of 'pure' and 'unadulterated') reverberates in Yeats's view that 'To speak... without fear or moral ambition, to come out from the shadow of other men's minds, to forget their needs, to be utterly oneself, that is all the muses care for' ${ }^{40}$ Kipling's 
'rapine, hate', and 'The laws we made and guard' are countered by Yeats's careful and complicated elegy for another imperialist, Robert Gregory, 'An Irish Airman Foresees his Death': 'Those that I fight I do not hate, / Those that I guard I do not love'. 41 'An Irish Airman Foresees his Death' poses obvious difficulties for Yeats: Gregory's political sympathies are more akin to Kipling's than to Yeats's; the crises in Gregory's personal life also necessitate some delicate negotiation in the poem in terms of its balancing both the absence and presence of motives for enlistment. ${ }^{42}$ Yet it is notable that Robert Gregory's 'fate' is also chosen, known in advance; it arises from a 'lonely impulse of delight'. Yeats's poem of ambiguous praise for Gregory thus attributes to him a gesture of individualism valued according to Yeats's own lights not Gregory's politics. Only in the later 'Reprisals' (1919), a poem unpublished in Yeats's lifetime, do Yeats and Kipling seem to converge, as Yeats writes his own poem of betrayal, revisiting Gregory's enlistment in the light of the Irish war of independence: 'Half-drunk or whole-mad soldiery / Are murdering your tenants there... Nor law nor parliament take heed'. But Yeats turns Kipling's rhetoric back on the war itself, on those who signed up for it, thinking it a 'such a fine affair', and on the (English) 'soldiery' engaged in their own kind of rapine and hate, light years away from the benign ‘Tommy' made famous by Kipling. The poem's condemnation of atrocities in Ireland transforms Gregory into one of the many 'cheated dead'. ${ }^{43}$

Sacrifice, as history has shown, isn't something on which any one group has purchase, since the sacrifice in the Great War (notably on the Somme) is as much part of the founding myth of Northern Ireland as the Rising is for the Republic. Kipling chose 'their name liveth for evermore' for the Imperial War Graves Commission as the inscription for the Stone of Remembrance in the cemeteries of the First World War. The phrase, drawn from Ecclesiasticus 44:12 ('And their children are within the covenant. Their seed standeth fast ... The people will tell of their wisdom, And the congregation will shew forth their praise') 
resonates, as we might expect, with Kipling's anti-Home Rule rhetoric; but it resonates too with Padraic Pearse's anti-imperial incitement to rebellion in 'The Rebel' ('I am come of the seed of the people... Beware of the risen people'), as well as with his terms of remembrance for the Easter Rising in 'The Mother' ('The generations shall remember them / And call them blessed). ${ }^{44}$ Yet in terms of sacrifice in the Rising, or on the Somme, there is an important difference at work - already intimated in the differences between Yeats and Kipling, and evident too in the struggle with the legacy of the First World War in Ireland over the last century. Where Yeats questions whether the ideological single-mindedness of the Rising's leaders may in some ways compromise their humanity, his 'terrible beauty' is nevertheless the willed individual act - individuals who are named, given personality, in 'Easter 1916'. Kipling, on the other hand, speaks for a group who are not so much making a sacrifice as, he argues, being sacrificed.

In that context, his 'We are the sacrifice' takes on a new emotional resonance for Ulstermen after 1 July 1916, where for all the willingness to serve in the Great War, to make the sacrifice Kipling's 1914 'For All We Have and Are' demanded of both England and Ulster, the experience of the Somme - of the soldiers treated as so much (anonymous) collateral damage - suggests a different kind of inhumanity at work. That sentiment is sometimes echoed in the writings of the English soldier poets too: Sassoon, for instance, in his July 1917 'Soldier's Declaration', railed against the 'political errors and insincerities for which the fighting men are being sacrificed' ${ }^{45}$ It is a sentiment irreconcilable with the idea of Yeatsian tragedy, and one of the reasons Yeats avoided direct engagement with the war experience, since tragedy should be, as he put it in his critique of Owen and the soldier poets, 'a joy to the man who dies'. ${ }^{46}$

Kipling's 'Ulster (1912)' may be little more than an historical curiosity now, its sentiments unrecognisable to the English conservative unionist and imperialist class from 
which and for whom he then spoke - even if his unionist principles still resonate in Northern Ireland. In part, this is because the year 1916 has historically eclipsed 1912 in ways no-one could then have anticipated, as the events of the Great War 1914-1918 eclipsed, at least on the world stage, the Irish quarrels of 1912-1916. One victim of that eclipse is Tom Kettle, who, having entered the fray against Kipling in 1912, and pre-empted the sacrificial rhetoric that would eventually surround the Easter Rising in 1916, was wrong-footed by his own enlistment in the First World War in 1914, noting with some bitterness of the Easter Rising rebels that 'These men will go down in history as heroes and martyrs, and I will go down - if I go down at all - as a bloody British officer'. ${ }^{47}$ In the best-known of Kettle's poems, 'To my Daughter Betty, the Gift of God', written just before he was killed in September 1916, he repositions the 'One place, one dream, one doom' of that earlier riposte to Kipling (whose own son had been killed at Loos in September 1915):

Know that we fools, now with the foolish dead,

Died not for flag, nor King, nor Emperor,

But for a dream, born in a herdsman's shed,

And for the secret Scripture of the poor. ${ }^{48}$

The political and historical ambiguity of 'not for flag, nor King, nor Emperor', while it affirms his anti-imperialism, also marks a move away from the Easter 'renewal' of his 1912 response to Kipling, or from Yeats's 'enough / To know they dreamed and are dead', to a rather different kind of 'dream, born in a herdsman's shed'. It is a poem written with full consciousness of the poetry associated with the Rising, but Kettle, experiencing modern warfare firsthand, eschews the heroic 'battle' envisaged by Padraic Pearse in a poem such as 'Christmas 1915 ' with its 'King'... born / To set bondsmen free'. ${ }^{49}$ That Kettle is at odds with his own 1912 rhetoric is evident in other ways too, since this poem's closing sentiment comes out of his support not for a Lenten Ireland's revolutionary potential, but out of his experience 
of the Dublin 1913 strike - a different kind of 'war', as he saw it, in which he sought a solution for workers caught 'in a desperate order of facts' ${ }^{50}$

The other poet eclipsed here, for different reasons, is Kipling himself, whose position in the world of letters before the Home Rule Crisis and the First World War was not the same after it. Yeats, as R.F. Foster notes, had always seen Swinburne not Kipling as 'the monarch to dethrone'. ${ }^{51}$ But others saw it differently, even before the war. In May 1913, Robert Frost wrote: 'Tagore comes to Yeats here as the greatest English poet. How slowly but surely Yeats has eclipsed Kipling. I have seen it with my own eyes. You would expect to see Tagore seeking Kipling for his Indian sympathies and interests. But no, he is drawn to Maeterlin[c]k on the continent and to Yeats on these islands'. ${ }^{52}$ For consolidation of that change, the Great War- a war which Kipling apparently embraced and Yeats apparently eschewed - is also partly responsible. Both poets were out of sympathy with some of the forces of modernity and the processes of democracy that reshaped the western world between 1914-18; but Kipling, as Lycett notes, found himself in 1918 in a 'hostile world he did not understand', acknowledging privately that he might be out of touch with the times. ${ }^{53}$ As such, he could hardly speak 'for' the times, as he had done in 1912 and 1914; the war put paid to the ‘imperialist journalist' already dismissed by Yeats in 1903. If this compromised his popular appeal, then by 1919, as T.S. Eliot pointed out, his place in English letters was no more secure: 'The arrival of a new book of his verse is not likely to stir the slightest ripple on the surface of our conversational intelligentsia... [M]alevolent fate has not even allowed him to be one of the four or five or six greatest living poets. ${ }^{54}$

By contrast, Yeats's self-reinvention, his embattled oppositional stance to the world's (dis)order after 1918 placed him at the heart of the 1920s 'modernist' enterprise - not always, as Louis MacNeice was later to argue, in a manner which was politically appealing, but which was without question aesthetically compelling. ${ }^{55}$ I have suggested that 'Easter 1916 ' 
talks back to 'Ulster (1912)' in the charged context of the First World War. More precisely, what we see in 'Easter 1916', as in Yeats's post-1914 career as a whole, is not so much a 'dialogue' with Kipling as it is, literally, an 'eclipse' of the (younger) poet so complete in its accomplishment that even the simple fact of its having taken place has never really, it seems, proven much worthy of note in the critical responses to both poets' work.

\section{NOTES}

${ }^{1}$ See http://www.ireland.ie/easter-weekend-events-dublin [accessed 04/12/16]

${ }^{2}$ Nicholas Grene, Yeats's Poetic Codes (Oxford: OUP, 2008), p.5

${ }^{3}$ Grene, Yeats's Poetic Codes, p.7.

${ }^{4}$ W.B. Yeats, 'September 1913' and 'Easter 1916', The Variorum Edition of the Poems of W.B. Yeats, ed. Peter Allt and Russell K. Alspach (London: Macmillan, 1956), pp. 289-90, $391-4$.

${ }^{5}$ This was noticed by Helen Vendler's student Nathan Rose. See Marjorie Perloff, “"Easter, 1916": Yeats's First World War Poem', The Oxford Handbook of British and Irish War Poetry, ed. Tim Kendall (Oxford: OUP, 2007), p.232.

${ }^{6}$ Yeats, Variorium, pp.391-4, 428-33.

${ }^{7}$ Grene, Yeats's Poetic Codes, pp.26-7.

${ }^{8}$ W.B. Yeats, 'Modern Poetry’ [1936], Essays \& Introductions (London: Macmillan, 1961), pp.499, 506

${ }^{9}$ Humphrey Carpenter, W.H. Auden: a biography (London: Allen \& Unwin, 1081), p.301. I am grateful for Rowan Williams for drawing my attention to this.

${ }^{10}$ W.B. Yeats, Autobiographies (London: Macmillan, 1955), p.128. 
${ }^{11}$ Alexander Bubb, Meeting Without Knowing It: Kipling and Yeats at the Fin de Síecle (Oxford: OUP, 2016), p.2.

${ }^{12}$ See W.B. Yeats, 'To Lady Augusta Gregory', 16 Nov. 1903. The note to the letter quotes the passage above from Marie Mattingly's interview with Yeats, which appeared in the US Sun in November 1903. The Collected Letters of W.B. Yeats: InteLex Electronic Edition (2002), vol. III [accessed 07/01/17].

${ }^{13}$ W.B. Yeats, 'To J.B. Yeats', 7 August [?1909], The Letters of W.B. Yeats, ed. Allan Wade (London: Rupert Hart-Davis, 1954), p.534

${ }^{14}$ W.B. Yeats, 'The Literary Movement in Ireland', in Ideals in Ireland, ed. August Gregory (1901; New York: Lemma, 1973), p.90.

${ }^{15}$ See Fran Brearton, The Great War in Irish Poetry (Oxford: OUP, 2000), pp.45-7.

${ }^{16}$ See James Longenbach, Stone Cottage: Pound, Yeats and Modernism (New York: OUP, 1988), pp. 112.

${ }^{17}$ Yeats, ‘To Henry James', 20 Aug [1915], Letters, ed. Wade, p.600.

${ }^{18}$ Yeats, 'Modern Poetry', 506.

19 ‘To W.B. Yeats', 14 April 1909, and ‘To Oliver Elton', 9 Dec. 1913, in J.B. Yeats: Letters to his son W.B. Yeats and others 1869-1922, ed. Joseph Hone (London: Faber, 1944), pp. $119,167$.

${ }^{20}$ Yeats, 'To Dorothy Wellesley', 21 Dec. [1936], Letters, ed. Wade, p.874.

${ }^{21}$ W.H. Auden, 'In Memory of W.B. Yeats' (1940), Selected Poems, ed. Edward Mendelson (London: Book Club Associates, 1979), p.82. This stanza was later cut.

${ }^{22}$ Rudyard Kipling, The Definitive Edition of Rudyard Kipling's Verse (London: Hodder \& Stoughton, 1940), p.500.

${ }^{23}$ Rudyard Kipling, 'Ulster (1912)', The Years Between (London: Methuen \& Co, 1919), pp.9-12; Definitive Edition, pp.232-3. 
${ }^{24}$ See R.F. Foster, W.B. Yeats: A life, vol II The Arch Poet (Oxford: OUP, 2003), p.64.

${ }^{25}$ Andrew Lycett, Rudyard Kipling (1999; London: Weidenfeld \& Nicolson, 2015) p.575.

${ }^{26}$ A.E., “"Ulster:” An Open letter to Mr Rudyard Kipling', London Daily News, 15 April 1912, p.3.

${ }^{27}$ T.M. Kettle, ‘A Note...', Freeman’s Journal, 11 April 1912, p.7.

${ }^{28}$ Kerryman, 15 June 1912, p.9.

${ }^{29}$ R.F. Foster W.B. Yeats: A Life, vol. I The Apprentice Mage (Oxford: OUP, 1997), p.459.

${ }^{30}$ Irish Times, 11 April 1912, p.6; Freeman’s Journal, 11 April 1912, p.7.

${ }^{31}$ The declaration, with initial signatures including Kipling's, appears in a letter to The

Times, under the headline 'Home Rule and Coercion', on 3 March 1914, p.7.

32 'Mr Kipling on Ulster', The Times, 18 May 1914, p.6.

${ }^{33}$ Ann Parry, The Poetry of Rudyard Kipling (Buckinghamshire: Open University Press, 1992), p.126.

${ }^{34}$ Kipling, 'The Covenant', The Covenanter, 20 May 1914, p.3.

${ }^{35}$ Parry, Poetry of Rudyard Kipling, p.126.

${ }^{36}$ Kipling, 'For All We Have and Are', The Times, 2 Sept. 1914, p.9.

${ }^{37}$ See Owen Dudley Edwards, 'Kipling and the Irish', London Review of Books, 10:3 (4 February 1988), pp. 22-3.

${ }^{38}$ W.B. Yeats, 'Introduction', The Oxford Book of Modern Verse (Oxford: Clarendon Press, 1936), p.xxxiv.

${ }^{39}$ Bubb, Meeting Without Knowing It, p.238.

${ }^{40}$ Yeats, 'J.M. Synge and the Ireland of his Time' [1910], Essays \& Introductions, p.339.

${ }^{41}$ Yeats, Variorum, pp. 328, 402. 
${ }^{42}$ For elucidation on this point, relating to Gregory's extramarital affair, see James Pethica, 'Yeats's “perfect man"', Dublin Review, no. 35 (Summer 2009):

http://thedublinreview.com/article/yeatss-perfect-man/ [accessed 08/01/17]

${ }^{43}$ Yeats, Variorum, p.791.

${ }^{44}$ Padraic Pearse, Rogha Dánta; Selected Poems, ed. Dermot Bolger (Dublin: New Island Books, 1993), pp. 23-4, 28.

${ }^{45}$ Siegfried Sassoon, 'Finished with the War: A Soldier's Declaration', quoted in Robert

Graves, Good-bye to All That (London: Jonathan Cape, 1929), p.321.

${ }^{46}$ Yeats, 'Introduction', Oxford Book of Modern Verse, p.xxxiv.

${ }^{47}$ Quoted in J.B. Lyons, The Enigma of Tom Kettle (Dublin: Glendale Press, 1983), p.293.

${ }^{48}$ In Gerald Dawe, ed., Earth Voices Whispering: An Anthology of Irish War Poetry (Belfast: Blackstaff Press, 2008), p.55.

${ }^{49}$ Pearse, Selected Poems, p.27,

${ }^{50}$ Tom Kettle, ‘A Word for Peace’, Freeman’s Journal, 23 September 1913, p.7.

${ }^{51}$ Foster, W.B. Yeats A Life, vol I, p.616 n.69.

${ }^{52}$ Robert Frost, 'To Sidney Cox', Selected Letters of Robert Frost, ed. Lawrance Thompson (London: Jonathan Cape, 1965), p.72.

${ }^{53}$ Lycett, Rudyard Kipling, pp. 660ff.

${ }^{54}$ T.S. Eliot, 'Kipling Redivivus', rev. of Kipling, The Years Between, The Athenaeum, 4645 (9 May 1919) 297-98.

${ }^{55}$ See Louis MacNeice, The Poetry of W.B. Yeats (1941; London: Faber, 1967), pp.191, 197. 